\title{
Test of the pathogenicity of two commercial Beauveria strains on third-instar larvae of the mango blossom gall midge, Procontarinia mangiferae (Felt) (Diptera: Cecidomyiidae)
}

Eléonore S. BriccA ${ }^{1,2}$, Samuel NiBouchE ${ }^{3}$, Hélène DeLATTE ${ }^{3}$, Frédéric NORMAND ${ }^{1}$, Paul Amouroux ${ }^{1,4 *}$

${ }^{1}$ CIRAD, Persyst, UPR HortSys, F-97455 Saint-Pierre, La Réunion, France, paul.amouroux@cirad.fr

2 Montpellier SupAgro, F-34060 Montpellier, France

${ }^{3}$ CIRAD, Bios, UMR PVBMT, F-97410 Saint-Pierre, La Réunion, France

4 Univ. la Réunion, UMR PVBMT, F-97410 Saint-Pierre, La Réunion, France
* Correspondence and reprints

Received 13 September 2013 Accepted 3 December 2013

Fruits, 2014, vol. 69, p. 189-194 (C) 2014 Cirad/EDP Sciences All rights reserved

DOI: 10.1051/fruits/2014008 www.fruits-journal.org

REsumen EsPañol, p. 194
Test of the pathogenicity of two commercial Beauveria strains on third-instar larvae of the mango blossom gall midge, Procontarinia mangiferae (Felt) (Diptera: Cecidomyiidae).

Abstract - Introduction. The invasive gall midge, Procontarinia mangiferae (= Erosomyia mangiferae Felt), is one of the most important flowering pests of mango orchards worldwide. To achieve chemical input reduction, developing integrated pest management (IPM) strategies using bio-control agents is pertinent. Materials and methods. We tested the pathogenicity of two commercial strains of the entomopathogenic fungi Beauveria on non-diapausing 3rdinstar larvae of $P$. mangiferae. Results and discussion. Neither the Beauveria sp. commercial strain Betel nor the B. bassiana strain Bb 147 were effective, even though they proved their pathogenicity on the control, Galleria mellonella. Hypotheses to explain the inefficiency of the two strains on P. mangiferae are discussed. Conclusion. Other strains of Beawveria or other entomopathogenic fungi or nematodes should be tested on diapausing and non-diapausing larvae of $P$. mangiferae.

Réunion / Mangifera indica / pests of plants / Procontarinia mangiferae / integrated pest management / Beauveria

Test de pathogénicité de deux souches commerciales de Beauveria sur le troisième stade larvaire de la cécidomyie des fleurs du manguier, Procontarinia mangiferae (Felt) (Diptera: Cecidomyiidae).

Résumé - Introduction. La cécidomyie des fleurs, Procontarinia mangiferae (= Erosomyia mangiferae Felt), est une espèce invasive et l'un des plus importants ravageurs de la floraison du manguier dans le monde. L'utilisation d'organismes de bio-contrôle est une stratégie pertinente de gestion intégrée des ravageurs pour réduire l'emploi de produits phytosanitaires. Matériel et méthodes. La pathogénicité de deux souches commerciales du champignon entomopathogène Beauveria a été testée sur des larves de $P$. mangiferae du troisième stade non diapausantes. Résultats et discussion. Malgré leur pathogénicité sur l'espèce témoin, Galleria mellonella, la souche commerciale Betel de Beauveria sp. et la souche Bb 147 de $B$. bassiana ne se sont pas montrées pathogènes sur les larves de P. mangiferae. Des hypothèses pour expliquer l'inefficacité des deux souches testées sont discutées. Conclusion. D'autres souches de Beauveria, ou d'autres champignons ou nématodes entomopathogènes, doivent être testés sur des larves diapausantes et non-diapausantes de la cécidomyie des fleurs du manguier.

Réunion / Mangifera indica / ravageur des plantes / Procontarinia mangiferae / gestion intégrée des ravageurs / Beauveria 


\section{Introduction}

Procontarinia mangiferae (Felt) is one of the species of gall midge (Diptera: Cecidomyiidae) that attack mango trees (Mangifera indica L.) [1]. This midge is considered to be indigenous to India and invasive in Thailand, Mauritius, Reunion Island, Iran, the West Indies and Brazil $[2,3]$; it causes economic damage in many countries $[4,5]$. Adults lay eggs on inflorescences and young leaves [6]. After hatching, larvae bore the plant tissues and cause the formation of galls. Larvae stay there for up to a week, completing their development. Then, third-instar larvae leave the mango tree to pupate in the soil. They can emerge about a week later or enter into diapause for up to several years. Adults stay alive for one to two days [7].

Gall midge populations have often been controlled in commercial farms with neonicotinoid, organophosphate, pyrethroid, organochlorine or carbamate insecticides [7-9]. Today, the use of some of these insecticides is prohibited because of their toxicity toward humans and the environment. Moreover, some new insecticides are ineffective against $P$. mangiferae [10] or need to be applied regularly during the blooming season [7]. Other ways have to be found to regulate populations of this pest without negative consequences for farmers, consumers or the environment [11]. Among these solutions, entomopathogens such as fungi [12] or nematodes [13] can be considered to control gall midge. Beauveria bassiana and B. brongniartii (Ascomycota: Hypocreales: Clavicipitaceae), naturally present in many soils around the world, are widely used as mycoinsecticides and considered safe for the environment and for living beings [14]. Some Beauveria species are known to infect some gall midges [15]. In France, two Beauveria strains are authorized for pest control ${ }^{1}$ : the $B$. bassiana strain

\footnotetext{
${ }^{1}$ Anon., e-phy, le catalogue des produits phytopharmaceutiques et de leurs usages, des matières fertilisantes et des supports de culture homologués en France, Minist. Agric. Agroalim., access. 21 Dec 2013, http://e-phy.agriculture.gouv.fr/.
}

Bb 147 (Ostrinil ${ }^{\circledR}$, Arysta Lifescience) is authorized against the corn borer (Ostrinia nubilalis (Hübner), Lepidoptera: Pyralidae) on corn and the palm moth (Paysandisia archon (Burmeister), Lepidoptera: Castniidae) on palm trees, and Beauveria sp. (Betel ${ }^{\circledR}$, Betel Reunion) is authorized against the white grub Hoplochelus marginalis (Fairmaire), Coleoptera: Scarabaeidae) on sugar cane. In our study, we tested the pathogenicity of these two commercial strains on $P$. mangiferae, with the aim of identifying a potential bio-control agent.

\section{Materials and methods}

\subsection{Collection of $P$. mangiferae larvae}

Third-instar P. mangiferae larvae were collected in orchards located in Saint-Gilles, Reunion Island $\left(21^{\circ} 02^{\prime} 33^{\prime \prime} \mathrm{S}, 55^{\circ} 13^{\prime} 45^{\prime \prime} \mathrm{E}\right)$. Tarpaulin traps containing water were installed in the afternoon under trees with damaged inflorescences. Larvae fallen from the inflorescences during the night were collected the next morning, an hour before starting the pathogenicity tests. The larval mortality was negligible with this collection technique. Dead or not very active larvae were discarded before the experiments.

\subsection{Beauveria strains}

Two commercial strains of Beauveria sp. were tested. The first one was the Beauveria sp. strain B 507 used in Reunion Island to control the sugar cane white grub Hoplochelus marginalis [16]. The commercial name of the fungal product is Betel ${ }^{\circledR}$ (Betel Reunion, Saint-Benoit, Reunion Island). The conidial suspension was directly obtained from the firm Betel Reunion. The initial Betel ${ }^{\circledR}$ suspension, $\mathrm{C}_{\mathrm{h}} 2$, had a concentration of $10^{8}$ spores $\cdot \mathrm{mL}^{-1}$. We diluted this suspension to obtain a second suspension, $\mathrm{C}_{\mathrm{h}} 1$, concentrated at $10^{6}$ spores $\cdot \mathrm{mL}^{-1}$, a concentration used to assess the biological activity of Beauveria sp. against Hoplochelus marginalis [17]. The initial concentration of $10^{8}$ spores $\cdot \mathrm{mL}^{-1}$ was also tested to assess the 
concentration effect on the pathogenicity of Beauveria sp. strain B 507.

The second strain tested was the Beauveria bassiana strain $\mathrm{Bb} 147$, used in the commercial product Ostrinil ${ }^{\circledR}$ (Arysta LifeScience, France). The strain was cultivated from a freeze-dried culture obtained from the Centre de Biologie et de Gestion des Populations (Montpellier, France). It was cultivated on medium containing antibiotics and anti-fungus: $18 \%$ agar, $10 \%$ glucose, 5\% yeast extract, $1.4 \% \mathrm{Na}_{2} \mathrm{HPO}_{4}, 1 \% \mathrm{KCl}, 0.7 \%$ $\mathrm{NH}_{4} \mathrm{NO}_{3}, 0.6 \% \mathrm{MgSO}_{4}, 0.5 \%$ chloramphenicol, $0.4 \% \mathrm{KH}_{2} \mathrm{PO}_{4}$ and $0.25 \%$ cycloheximide ethanol. Once the fungi had sporulated, we prepared a $20-\mathrm{mL}$ spore suspension and diluted it to prepare a $\mathrm{C}_{\mathrm{b}}$ suspension at a concentration of $9.10^{6}$ spores $\cdot \mathrm{mL}^{-1}$. It was not possible to obtain a more concentrated suspension, and only this one was tested for $B$. bassiana strain $\mathrm{Bb} 147$ since this concentration was intermediate between the two concentrations tested for Beauveria sp. strain B 507. Conidial suspension concentrations were determined using a Malassez hemocytometer [18]

\subsection{Verification of the virulence of the Beauveria strains}

Fourth-instar larvae of the wax moth Galleria mellonella L. (Lepidoptera: Pyralidae) were used as a control to test the virulence of the two Beauveria strains [19, 20]. The larvae came from a laboratory population reared on artificial media.

Sixty G. mellonella larvae were inoculated with the suspension $\mathrm{C}_{\mathrm{h}} 2$ of the Beauveria sp. B 507 strain, and 30 larvae with the suspension $\mathrm{C}_{\mathrm{b}}$ of $B$. bassiana $\mathrm{Bb} 147$. Inoculation consisted of immersing larvae in the suspension for two seconds. Two control groups of 30 larvae each were immersed in distilled water. Then, larvae were placed in individual $25-\mathrm{mL}$ hermetic plastic boxes with $0.4 \mathrm{~g}$ beeswax and an $8-\mathrm{cm}^{2}$ piece of Whatman paper humidified with $0.5 \mathrm{~mL}$ distilled water. Larvae were stored at $25^{\circ} \mathrm{C}$ After 21 days, dead and alive larvae were counted.

\subsection{Pathogenicity test on gall midge larvae}

To test the effect of the two Beauveria strains on $P$. mangiferae, larvae were inoculated using the same method as for $G$. mellonella. Groups of 30 larvae were inoculated with suspensions of Beauveria sp. B 507 strain $C_{h} 1, C_{h} 2$, or with distilled water (control group). Then, each group was equally separated into three $50-\mathrm{mL}$ hermetic plastic boxes containing $10 \mathrm{~g}$ of sand humidified with $1 \mathrm{~g}$ of distilled water. Three repetitions were performed to achieve a total of 90 larvae per treatment. For the B. bassiana $\mathrm{Bb} 147$ strain, thirty larvae were inoculated with the suspension $C_{b}$ or with distilled water. Four repetitions were performed to achieve a total of 120 larvae per treatment. Pathogenicity tests were performed at $25^{\circ} \mathrm{C}$. At this temperature, adult emergence occurs between 5 and 6 days (data not shown). Ten days after the inoculation, the number of emerged adults was counted.

\subsection{Statistical analysis}

We performed the exact Fisher's test to assess the significance of the differences in mortality rates between the inoculated and the control groups.

Generalized linear models with binomial distribution were used to test the effect of each Beauveria strain on the emergence of P. mangiferae. Statistical analyses were performed with the $\mathrm{R}$ software, version 2.15 [21].

\section{Results and discussion}

Mortality of G. mellonella larvae was significantly higher in groups inoculated with Beauveria sp. B 507 and B. bassiana Bb 147 than in control groups (table I), confirming the viability and virulence of both strains.

Analyses showed that neither Beauveria strain had a significant effect on the emergence of $P$. mangiferae (table II). None of the strains was efficient in controlling the 
Table I.

Mortality of Galleria mellonella larvae inoculated with the two strains of Beauveria sp. or dipped in distilled water (p-value $<0.01)$.

\begin{tabular}{lccc} 
Strains & Treatment & \multicolumn{2}{c}{ Number of larvae } \\
& & Total & Dead at 21 days \\
\hline Beauveria sp. B 507 & Dipped in water for control & 30 & 5 \\
& Inoculated with $10^{8}$ spores $\cdot \mathrm{mL}^{-1}\left(\mathrm{C}_{\mathrm{h}} 2\right)$ & 60 & 59 \\
B. bassiana Bb 147 & Dipped in water for control & 30 & 12 \\
& Inoculated with $9 \times 10^{6}$ spores $\cdot \mathrm{mL}^{-1}\left(\mathrm{C}_{\mathrm{b}}\right)$ & 30 & 30
\end{tabular}

\section{Table II.}

Emergence of Procontarinia mangiferae adults 10 days after exposure of larvae to Beauveria sp. strain B 507, B. bassiana strain $\mathrm{Bb} 147$ and distilled water.

\begin{tabular}{lcccc} 
Strain & Treatment & $\begin{array}{c}\text { Number } \\
\text { of larvae }\end{array}$ & $\begin{array}{c}\text { Mean of adult emergence }{ }^{1} \text { at } 10 \text { days } \\
(\% \pm \text { standard error })\end{array}$ & $p$-value \\
\hline Beauveria sp. B 507 & Dipped in water for control & 90 & $74.4 \pm 11.3$ & 0.088 \\
& Inoculated with $10^{6}$ spores $\cdot \mathrm{mL}^{-1}\left(\mathrm{C}_{\mathrm{h}} 1\right)$ & 90 & $80.0 \pm 14.1$ & $65.7 \pm 18.1$ \\
& Inoculated with $10^{8}$ spores $\cdot \mathrm{mL}^{-1}\left(\mathrm{C}_{\mathrm{h}} 2\right)$ & 90 & $85.8 \pm 13.8$ & 0.564 \\
B. bassiana Bb 147 & Dipped in water for control & 120 & $88.3 \pm 22.9$ &
\end{tabular}

${ }^{1}$ In each treatment, adult emergence is expressed as the mean percentage of emerged adults (for the three batches of 30 larvae) relative to the number of larvae initially present.

immediate emergence of $P$. mangiferae and they therefore showed no pathogenic effect on the larvae.

To explain these results, several hypotheses can be suggested. Firstly, another inoculation method could have been used. In other studies, the soil [22], the leaves [23] or the bark [24], which are shelters for the larvae, are drenched or sprayed with a conidial suspension, instead of spreading the conidia directly on the body of the larvae. Secondly, the life cycles of $P$. mangiferae and of these strains of Beauveria sp. might not be compatible because the fungus incubation period is longer than the non-diapausing larval development tested here [14]. Thereby, the spores would not have enough time to germinate and penetrate the larvae before the pupal moulting. However, these entomopathogenic fungi could infest larvae which enter diapause in the soil, or have an effect on the emerged adult flies and their fertility, as observed on the red palm weevil, Rhynchophorus ferrugineus (Olivier) (Coleoptera: Curculionidae) [25]. The third hypothesis is that the larvae were not susceptible to the fungus. The peptides and amino acids of the larval cuticle may not be recognized by the fungi, or, once the fungus has penetrated, the larval immune system may be efficient enough to enable the larvae to finish their development into adults [14]. From these experiments, we conclude that other strains need to be tested against $P$. mangiferae since, for example, specific strains of Beauveria sp. are effective against pine gall midges, Thecodiplosis japonensis Uchida et Inouye (Diptera: Cecidomyiidae) $[15,26]$. Therefore, it is necessary to include these strains in future tests.

Controlling gall midge populations in the soil is a way to develop IPM strategies. Controlling populations in diapause may be another solution, and we may test these 
strains of Beauveria sp. on diapausing individuals. Other biological solutions could be tested, such as the fungus Metarbizium anisopliae [27].

\section{Acknowledgments}

The authors would like to thank Richard Tibere and Magali Hoarau for their technical assistance in the laboratory and the rearing of G. mellonella larvae and B. bassiana, Mr. Zuin for providing the Betel ${ }^{\circledR}$ suspension, and Mr. Law-Yat for allowing us to visit his orchards and collect larvae frequently. This work was funded by the European Agricultural Fund for Rural Development (EAFRD, Bilan de Santé de la $P A C$, No 11111D974000019) and CIRAD.

\section{References}

[1] KolesikP., RiceA.D., Bellis G.A., Wirthensohn M.G., Procontarinia pustulata, a new gall midge species (Diptera: Cecidomyiidae) feeding on mango, Mangifera indica (Anarcadiaceae), in northern Australia and Papua New Guinea, Aust. J. Entomol. 48 (2009) 310 316.

[2] Gagné R.J., Update for a catalog of the Cecidomyiidae (Diptera) of the world, Digit. vers. 1, USDA, Washington, 2010, http:// www.ars.usda.gov/SP2UserFiles/Place/ 12754100/Gagne_2010_World_Catalog Cecidomyiidae.pdf.

[3] Anon., Crop Protection Compendium, CAB Int., Wallingford, U.K., 2004.

[4] Amouroux P., Normand F., Survey of mango pests on Réunion Island, with a focus on pests affecting flowering, Acta Hortic. 992 (2013) 459-466.

[5] Whitwell A.C., The pest/predator/parasitoid complex on mango inflorescence in Dominica, Acta Hortic. 341 (1993) 421-432.

[6] Amouroux P., Normand F., Nibouche S., Delatte H., Invasive mango blossom gall midge, Procontarinia mangiferae (Felt) (Diptera: Cecidomyiidae) in Reunion Island: ecological plasticity, permanent and structured populations, Biol. Invasions 15 (2013) 16771693.
[7] Prasad S.N., The mango midge pests, Cecidological Soc. India, Allahabad, India, 1971.

[8] Abbas S.R., Verghese M., Fasih M., Studies on the mango inflorescence midge, Erosomyia indica Grover, Acta Hortic. 231 (1989) 593-596.

[9] Wu Q.J., Zhao J.Z., Taylor A.G., Shelton A.M., Evaluation of insecticides and application methods against Contarinia nasturtii (Diptera : Cecidomyiidae), a new invasive insect pest in the United States, J. Econ. Entomol. 99 (2006) 117-122.

[10] Barbosa F.R., Gonçalves M.E., De Souza E.A., Chemical control of Erosomyia mangiferae on mango trees at the Sao Francisco river valley, Brazil, in: de Queiros Pinto A.C., Lederman I.E., Fernandes Bezerra J.E., Canto Pereira M.E., Elesbão Alves R., Barbosa de Souza V.A. (Eds.), Program and Abstracts, VII Int. Mango Symp., Recife, Brasil, 2002, pp. 261-261.

[11] Malézieux E., Designing cropping systems from nature, Agron. Sustain. Dev. 32 (2012) 15-29.

[12] Keller S., Wilding N., Entomophthora brevinucleata sp. nov. [Zygomycetes, Entomophtphoraceae], a pathogen of gall midges [Dip.: Cecidomyiidae], Entomophaga 30 (1985) 55-63.

[13] Corlay F., Boivin G., Bélair G., Efficiency of natural enemies against the Swede midge Contarinia nasturtii (Diptera: Cecidomyiidae), a new invasive species in North America, Biol. Control. 43 (2007) 195-201.

[14] Zimmermann G., Review on safety of the entomopathogenic fungi Beauveria bassiana and Beauveria brongniartii, Biocontrol Sci. Technol. 17 (2007) 553-596.

[15] Shin S.C., Park S.J., Lee S.M., Choi K.S., Lee S.G., Lee C.Y., Pathogenicity of Beauveria spp. isolated from Korea against the pine needle gall midge (Thecodiplosis japonensis Uchida and Inouye) and their physiological characterization, FRI J. For. Sci. (Seoul) 59 (1998) 57-63.

[16] Neuvéglise C., Brygoo Y., Riba G., 28s rDNA group-I introns: a powerful tool for identifying strains of Beauveria brongniartii, Mol. Ecol. 6 (1997) 373-381.

[17] Neuvéglise C., Brygoo Y., Vercambre B., Riba G., Comparative analysis of molecular and biological characteristics of strains of Beauveria brongniartii isolated from insects, Mycol. Res. 98 (1994) 322-328. 
[18] Rodriguez-Tudela J.L., Chryssanthou E., Petrikkou E., Mosquera J., Denning D.W., Cuenca-Estrella M., Interlaboratory evaluation of hematocytometer method of inoculum preparation for testing antifungal susceptibilities of filamentous fungi, J. Clinic. Microbiol. 41 (2003) 5236-5237.

[19] Hussein K.A., Abdel-Rahman M.A.A. Abdel-MallekA.Y., El-MaraghyS.S., JooJ.H., Pathogenicity of Beauveria bassiana and Metarhizium anisopliae against Galleria melIonella, Phytoparasitica 40 (2012) 117-126.

[20] Powell J.R., Webster J.M., Target host finding by Steinernema feltiae and Heterorhabditis bacteriophora in the presence of a nontarget insect host, J. Nematol. 36 (2004) 285-289.

[21] Anon., R: A language and environment for statistical computing, $R$ foundation for statistical computing, R Development Core Team, Vienna, Austria, 2012.

[22] Wraight S.P., Ramos M.E., Synergistic interaction between Beauveria bassiana and Bacillus thuringiensis tenebrionis-based biopesticides applied against field populations of Colorado potato beetle larvae, J. Invert. Pathol. 90 (2005) 139-150.

[23] Wraight S.P., Carruthers R.I., Production, delivery, and use of mycoinsecticides for control of insect pests on field crops biopesticides: use and delivery, in: Hall F.R., Menn J.J. (Eds.), Humana Press, Totowa, N.J., U.S.A., 1999.

[24] Dean K.M., Vandenberg J.D., Griggs M.H., Bauer L.S., Fierke M.K., Susceptibility of two hymenopteran parasitoids of Agrilus planipennis (Coleoptera: Buprestidae) to the entomopathogenic fungus Beauveria bassiana (Ascomycota: Hypocreales), J. Invert. Pathol. 109 (2012) 303-306.

[25] Dembilio Ó., Quesada-Moraga E., SantiagoAlvarez C., Jacas J.A., Potential of an indigenous strain of the entomopathogenic fungus Beauveria bassiana as a biological control agent against the Red Palm Weevil, Rhynchophorus ferrugineus, J. Invert. Pathol. 104 (2010) 214-221.

[26] Seo J.B., Jin B.R., Shin S.C., Park H.Y., Lee B.Y., Chang K.L., Kang S.K., Isolation of entomopathogenic fungi for infection to the pine gall midge, Thecodiplosis japonensis, from the forest soil in Korea, Korean J. Appl. Entomol. 34 (1995) 368-372.

[27] Leles R.N., D'Alessandro W.B., Luz C., Effects of Metarhizium anisopliae conidia mixed with soil against the eggs of Aedes aegypti, Parasitol. Res. 110 (2012) 15791582.

\section{Test de patogenicidad de dos cepas comerciales de Beauveria en el tercer estado larvario de la cecidomia de las flores del mango, Procontarinia mangiferae (Felt) (Diptera: Cecidomyiidae).}

Resumen - Introducción. La cecidomia de las flores, Procontarinia mangiferae (= Erosomyia mangiferae Felt), es una especie invasiva y una de las plagas mundiales más importantes de la floración del mango. El uso de organismos de control biológico representa una estrategia pertinente de gestión integrada de las plagas para reducir el uso de productos fitosanitarios. Material y métodos. La patogenicidad de dos cepas comerciales del hongo entomopatógeno Beauveria se testeó en las larvas de P. mangiferae del tercer estado no diapausante. Resultados y discusión. A pesar de su patogenicidad en la especie testigo, Galleria mellonella, la cepa comercial Betel de Beauveria sp. y la cepa Bb 147 de B. bassiana no resultaron ser patógenas en las larvas de $P$. mangiferae. Se discutieron varias hipótesis para explicar la ineficacia de las dos cepas testeadas. Conclusión. Se deben testear otras cepas de Beauveria, u otros hongos o nematodos entomopatógenos, en larvas diapausantes y no diapausantes de la cecidomia de las flores del mango.

Reunión / Mangifera indica / plagas de plantas / Procontarinia mangiferae / gestión de lucha integrada / Beauveria 